\title{
Social Capital Mapping of Indonesia Return Migrant Workers as Development Resource in Lampung Timur Regency
}

\author{
Meiliyana $^{1 *}$, Ita Prihantika ${ }^{2}$, S. Indriati Caturiani ${ }^{3}$ \\ 1, 2,3 Public Administration Department, Universitas Lampung \\ *Corresponding author: meiliyana@fisip.unila.ac.id
}

\begin{abstract}
The literatures that exist shows that most researchers only focus on the pre-departure and placement of the migrant workers in their destination countries. There is still very limited literature about the potential of return migrant workers as a development capital. In fact, if managed properly, returnees can have positive impacts not only in terms of the economy through remittances they send to their hometown, but also social impact on the surrounding community. This research purposes are ;1) explore the socio-cultural values brought back by return migrant workers to the hometown and how these values affect the surrounding community 2) identify the benefits of social remittances brought by return migrant workers and how social remittances can improve the quality of life of returnees, families and surrounding communities, 3) identify the efforts have been done by stakeholders on organizing returnees as well as identify relevant policies exist, 4) identify and absorb return migrant workers aspiration about how they see themselves as development agent. The research approach used is a qualitative approach with case study methods. Collecting data methods are interview, observations and documentation.
\end{abstract}

Keywords: social capital, return migrant workers, development

\section{INTRODUCTION}

As the country which has huge population, Indonesia is one of the main worldwide resource for migrant workers. Diagram below illustrates the data of Indonesian Migrant workers deployment from 2011 to 2016. The data shows that number of migrant workers from Indonesia decreases within last five years. This is due to government efforts to reduce the number of informal overseas workers. Even the government of Indonesia under Joko Widodo's administration gave a sign to stop sending informal workers overseas.

Migration addresses impacts, both for an origin country and a destination country. Migrant workers contribute to economic development of their home countries through money that sending home (remittances) to support their family. Although remittance used mostly ninety eight percent for daily expenses of family members who staying in hometown [1], Another research [2] found that remittance has an influence on economic activity, since the family income of migrants increased. As the result, remittance also has an influence on socio cultural development at migrants hometown, for example the change level of education within migrants family.

Typically labor from Indonesia is a short term contract or temporary labor who works in another country for a certain period, usually around two years. Having finished their contract they would return to home country, renew the employment contract or settled down back in their hometown in Indonesia. Along with the fact that there are many numbers of international migrant workers from Indonesia, so I assume there are also a lot of numbers of returnees in Indonesia. According to the United Nations Statistics Division [3], returning migrants are "persons returning to their country of citizenship after having been international migrants (whether short term or long-term) in another country and who are intending to stay in their own country for at least a year". According to this definition, a migrant's home country refers to his nationality. 
In the period of their stay abroad, migrants have an opportunity to gain capital and forming networks of relationships and acquiring knowledge from their new country of residence [4]. As they return home with money and experiences, competences and foreign language, they could use those to make their life better than before they leave for working overseas.

Along with that, [5] and Former Minister of Manpower and Transmigration of Indonesia have argued that, "only remittances is not enough to develop local economy but the creativity of returning migrants is more important." Furthermore, according to Levitt [6] there is "social remittances" which refers to accumulated new skills, ideas, and practices during their stay in destination countries that are not necessarily turned into productive effects in economic terms but aim in poverty reduction.

Based on this argument I argue that it is critical to organize this sources institutionally in order to maximize the benefit of migration for development. Thus, the main question of this study is what policies should be initiated by the government to take advantage of the positive impact of the workers. This of course must start from identifying the potentials of the workers who are obtained by them while living and working in the destination country.

This study was conducted in East Lampung Regency which is the area that sends the most migrant workers from Lampung province.

The placement of migrant workers from Lampung Province in 2019 (until February) amounted to 3,084 people. Of the total number of these which are placements from East Lampung Regency in the period 2019 (until February), there were 653 people in January and 477 people in February, bringing the total to 1,130 people.

According to literatures, there is a lack on current study on potential positive social impact of the return migrant workers in Indonesia which in long term could be potential for development. So that this study aims to provide a wider knowledge on the issue about impacts of social remittances bring by the return migrant. This study also provide a new context of the study due to this research is conducted in East Lampung Regency Indonesia, one of major sending overseas workers in Indonesia

\section{LITERATURE REVIEW}

\subsection{Return International Migrant Workers}

\subsubsection{In a Global Context}

For many migrants, returning home is an expectation that attract them and something that keep their positive spirit alive during their migration journey. Especially for those who was leaving their home country under temporary programs [4].

Furthermore, from the brief explanation in the previous section, it could be argued that such experience and knowledge acquired by overseas migrants would be benefit for development. Some scholars have been conducted research discussing about positive values being brought by return migrants. In his article [7] discuss about potential profit brought by return migrant to home country. But his research did not provide clearer argument on how to govern that profit to promote development in home country. Meanwhile [8] also reveal about educational migrants in Nepal who do not create massive economic remittances for local development, but they contribute in important social remittance practices such as teaching in local schools, supporting women organizations, and sharing knowledge. Nevertheless, it fails to explore more about using the social remittance for local development. Moreover [9] simply describes about the impact of international migration for family. It does not take into account the impact for community especially when migrants decide to return and reside in home country. This gives a sign that more research in this area is urgent to be conducted to have far investigation about importance of having new knowledge and new experience after living overseas to contribute to local community in sending country.

There are studies about applying social remittance for community empowerment which has been pointed out by [10] and [11] both research have illustrated on return migrants who bring personal new knowledge, skills, and potential beneficial relationship acquired during their stay abroad, and also such ideas of prosperity which make possible for them to introduce new forms of leadership and community action in their home village. However, the study [10] only discusses about "south to south" migration and also only explores about management of natural resources. Meanwhile [11] claimed that social remittances would be useful for community but it explains that those social remittances difficult to be applied, so a more intensive research should be done to investigates how to put aside the barriers.

\subsubsection{In Indonesian Context}

This section will begin to discuss [12] and [13] that reveal about experiences of return migrant workers while their live overseas. Nurcahyati in her paper describe that exporting labor is one solution to alleviate the long term impact of 1997/1998 economic crisis also explains about the experience of three females returnees during their work in Saudi Arabia. This study makes 
clear how those females coped and adapted with the challenges of life and work in foreign country in order to pursuing their goals. It shows those female migrants could create strategies to deal with difficulties at some point in their working journey. This experiences could be developed in a positive way and share it with their environment.

Meanwhile [13] explored about three female return migrants from East Nusa Tenggara province, Indonesia which one of poorest region in the country. According to this research, through migration women no longer restricted their identity as mother, sister or daughter. Having experienced as transnational migrants, offer them an opportunity to redefine themselves as a salary person, a city occupant, a traveler, a consumer, working person with limited free time. Migration stimulates those women "self-conscious recognition" to themselves. So that further study about the potential of returnees is needed and organizing them institutionally also important to increase the advantage of migration.

Others researches that discusses on Indonesia return migrant workers $[14 ; 15 ; 16 ; 17]$ are aim to discuss about return migrant workers and the efforts have been done to manage them. But, none of the research discuss about the impact of social remittances gained by migrant workers during their sojourn overseas. Those studies only able to look the protection for return migrant workers during their journey to their village and some efforts have been done to assure that those return migrants would survive and will not do second migration.

\section{METHODOLOGY}

This research is a qualitative research with a case study design. In this study they are: return migrant workers in East Lampung Regency and logal government related to the study.

Informants were selected by using purposive sampling technique, namely the method of determining the informants who were determined intentionally on the basis of criteria or sample objectives.

\section{RESULTS AND DISCUSSION}

\subsection{Internal Condition}

East Lampung Regency is one of the regencies in Lampung Province which has an area of approximately $5,325.03 \mathrm{~km} 2$, consisting of 24 sub-districts and 264 villages/kelurahan. In 2014 the population of East Lampung reached 1,105,990 people and is supported by the potential of the region that has.

\subsection{Employment in East Lampung Regency}

The total population of East Lampung Regency is $1,110,340$ people with a composition of 565,734 men and 544,597 women. Of this number, 578,338 people are in the labor force, and 221,390 people are not in the labor force, so the total open unemployment rate is $2.64 \%$

The main job categorization of East Lampung residents is self-employment as many as 105,613 people, small business being assisted by temporary/unpaid workers as many as 133,286 people, small business being assisted by permanent workers/paid workers as many as 14,937 people, 108,668 workers/employees/salary person, 85,367 freelancers and workers family/unpaid as many as 115,194 people. Employment opportunities that are not able to absorb the entire existing workforce, encourage residents of the labor force to become migrant workers abroad. Throughout 2021, East Lampung Regency ranks fifth nationally as the largest sending area for migrant workers in Indonesia with 2,594 people during the period January - August 2021.

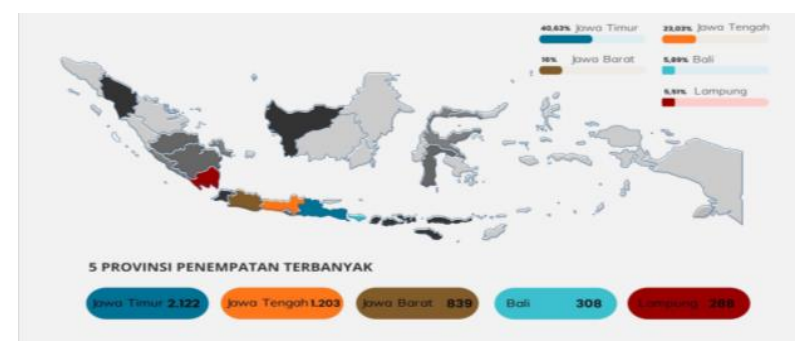

Figure 1. Migrant Workers Placement Data for August 2021 By Province

Source: bp2mi.go.id.

\subsection{Potential of Indonesian Migrant Workers in East Lampung Regency}

East Lampung Regency contributed the most migrant workers in Lampung Province. Based on data from the Directorate General of Immigration as of January 1, 2019-December 31, 2019, the departure of immigrant workers amounted to 8983 people, while the returnees amounted to 4592 people, then in 2020 the departure of migrant workers amounted to 2648 people, while the return of migrant workers amounted to 1159 people.

The countries targeted in 2019 are 15 countries: Singapore, Hong Kong, Malaysia, Poland, Brunei Darussalam, South Korea, Saudi Arabia, Papua New Guinea, Zambia, Niger, United Arab Emirates (UAE), Bahrain, Qatar, Japan. Meanwhile, in 2020 the destination countries for the departure of Indonesian migrant workers are 11 countries, namely Singapore, Hong Kong, Malaysia, Poland, Taiwan, Brunei Darussalam, South Korea, Saudi Arabia, Japan, Qatar. 


\subsection{Potential of Indonesian Return Migrant Workers in Stakeholder Perspective}

The interview was carried out in a structured face-toface with the resource person in charge at Local Government, to get information about socio-cultural values such as leadership, problem solving, or learning communities etc. what migrant workers take with them when they return home and how these values affect society.

From the interview revealed revealed that there were no socio-cultural values brought by return migrant workers when they returned to their hometown and no influence on the surrounding community, but it is mentioned that experiences such as economic activities taught for the community, and helping the closest people to go abroad.

From the interview session, it ois also stated the average use of remittances is for buying land, building houses and buying rice fields, some are also opening small businesses.

\subsection{Potential of Indonesian Return Migrant Workers In Their Own Perspective}

The data from Focus group discussion (FGD) with returnees revealed that only a few of them realize about social remmitances they acquired at destination countries. As they don't realize what social values they bring home, they don't exercise it to influence their society and family.

There are two returnees who realize about changing society in their home country by using social remmittances they bring from country where they worked overseas. A man who worked at mushroom cultivation in Malaysia for seven years, decided to come back to home country because he wants to assist the community which often experienced crop failure. He introduced and initiated mushroom cultivation to the society in his village. According to him, crop growing mushroom has no season so it will be more sustainable for the population. He also applies his network he has in the country where he worked abroad. Another man who work in Korea as a crew on ship initiated a training institute at his home village. According to him, it is necessary for those who want to work as a crew on ship to have a basic knowledge about safety. Its training that he commence will issue certificate of competency after completion the training in this institute.

\section{CONCLUSIONS}

This research is able to draw the conclusions as follows:

1. Explored the socio-cultural values brought back by migrant workers to the campong page and how those values affect the surrounding community

2. Identified the benefits of social remittances brought by return migrant workers and how social remittances can improve the quality of life of migrant workers, families and surrounding communities

3. Identified the efforts that stakeholders have made to organize PMI including identifying relevant activities

4. Identified and recognized how return migrant workers see themselves as development agent.

\section{RECOMMENDATIONS}

In particular, policies are needed from the Regional Government of East Lampung Regency to be able to elaborate and optimize the social potential of PMI by being covered by local regulations.

\section{REFERENCES}

[1] Raharto, Aswatini (2011). The Migratory Experience Of Returned Migrant Domestic Workers : The Example Of Indonesia. Presented at Workshop on Strengthening Dialogue between ESCWA and ESCAP Countries on International ESCWA and ESCAP Countries on International Migration and Development, in Beirut 28-30 June 2011

[2] Syamsuri, Suhaimi (2005). Dampak Remitan Terhadap Perubahan Perilaku Konsumsi Migran Di Daerah Asal (Studi di Desa Rensing Kecamatan Sakra Barat Kabupaten Lombok Timur). Thesis. Universitas Gadjah Mada Yogyakarta

[3] United Nations Statistics Division (1998), Recommendations on Statistics of International Migration,Revision 1. New York United Nations

[4] Organization for Economic Cooperation and Development. 2008. International Migration Outlook, Part III Return Migration - A New Perspective. SOPEMI. OECD: Paris

[5] Piper, Nicol. (2013). Contribution of Migrant Domestic Workers to Suistanable Development. UN Women.

[6] Levitt, Peggy. (1998). Social Remittances: Migration-Driven Local-Level Forms of Cultural Diffusion'. International Migration Review 32, no. 4: 926-948.

[7] Dustmann, Christian, Itzhak Fadlon \&Yoram Weiss. (2011). Return migration, human capital accumulation and the brain drain. Journal of Development Economics Vol. 95 p.58-67 
[8] Agergaard, Jytte \&Ditte Broegger. (2016). Returning home: migrant connections and visions for local development in rural Nepal, Geografisk Tidsskrift-Danish Journal of Geography, 116:1, 71-81.

[9] Hugo, Graeme. (2002). Effects of International Migration on the Family in Indonesia. Asian and Pacific Migration Journal, Vol. 11, No. 1.

[10] Montefrio, Marvin Joseph F, Yasmin Y. Ortiga, \& Ma. Rose Cristy B. Josol. (Spring 2014). 'nducing Development: Social Remittances and the Expansion of Oil Palm. IMR, 48 (1):216-242

[11] Ge, Jinghua, Bernadette P., Resurreccion, Rebecca Elmhirst. (2011). Return migration and the reiteration of gender norms in water management politics: Insights from a Chinese village. Geoforum 42; $133-142$

[12] Nurchayati. (2011). Bringing Agency Back In: Indonesian Migrant Domestic Workers in Saudi Arabia. Asian and Pacific Migration Journal, Vol. 20, Nos.3-4

[13] Williams, Chatarina P. (2008), Female transnational migration, religion and subjectivity: The case of Indonesian domestic workers, Asia Pacific Viewpoint, Vol. 49, No. 3, ISSN 13607456, pp344-353

[14] Kloppenburg, Sanneke \& Peter Peter. (2012). Confined Mobilities : Following Indonesian Migrant Workers On Their Way Home. Tijdschriftvoor Economischeen Sociale Geografie , Vol. 103, No. 5, pp. 530-541.

[15] Baharudin, Erwan. (2007). Perlindungan Hukum terhadap TKI di Luar negeri Pra keberangkatan, penempatan dan Purna Penempatan. Puspen Jurnal Ilmiah: Lex jurnalica, Vol. 4, No.3.

[16] Ningsi, Anggun Gita Ayu (2016). Startegi Pemberdayaan Purna Tenaga Kerja Indonesia (Purna TKI) (Studi pada Pos Pelayanan Penempatandan Perlindungan Tenaga kerja Indonesia Kabupaten Banyuwangi). Jurnal Adminisrasi Publik, Vol 4, No 11

[17] Meiliyana, S. Indriati Caturiani, Ita Prihantika (2016). Koordinasi Antar Organisasi Dalam Pengelolan Purna Buruh Migran di Kabupaten Lampung Timur, Provinsi Lampung. Laporan Penelitian, Universitas Lampung.

[18] AS, M. (2006, Juni 17). Etika Protestan dan Spirit Kapitalisme. Diambil kembali dari NU Online: https://www.nu.or.id/post/read/8016/etikaprotestan-dan-spirit-kapitalisme 